\title{
The Correlation between Cognitive Styles and Student's Reading Comprehension
}

\author{
Putri Nurus Sakina ${ }^{1}$, Desi Surlitasari Dewi ${ }^{2}$, Aulia Putri ${ }^{3}$ \\ English Education Department \\ University of Riau Kepulauan \\ putri.nurus.sakina@gmail.com ${ }^{1}$, belldaisy46@gmail.com ${ }^{2}$, auliaputri1983@yahoo.com³
}

\begin{abstract}
The objective of this study was to find out whether there is any correlation between cognitive style and student's reading comprehension. The researcher limited the cognitive style in this study in Field Dependence and Field Independence. For example, students with Field dependence tend to have low reading comprehension because they difficult to construct their own perception and to find the information that not exactly written in the text. The research design was correlational research. The population of this research was 271 students of Eleventh Grade of SMAN 3 Batam in the Academic Year 2015/2016. The population was selected simple random sampling technique. Embedded Figure Test (EFT) and Reading comprehension test were used as the instrument of this research. Then the researcher analyzed the correlation by using Spearman Ranked Correlation formula to correlate both cognitive style (variable $X$ ) and students reading comprehension (variable $Y$ ). The result showed that $Z_{\text {counted }}$ is 5.157 and $Z_{\text {table }}$ is 1.96. It means $Z_{\text {counted }}$ is greater than $Z_{\text {table }}$ and Ho is rejected and Ha is accepted. The researcher found out that there was a significant correlation between cognitive style and student's Reading Comprehension at Eleventh Grade of SMAN 3 Batam in the Academic Year 2015/2016.
\end{abstract}

Keywords : cognitive style, field dependence, field independence and reading comprehension.

\section{INTRODUCTION}

Cognitive style has important role in reading comprehension. Cognitive style as one of factors in reading comprehension affects the way people analyzing and processing the information of the text. Everyone has their own characteristics in the way they processing the information. The way includes how to they perceiving, remembering, thinking, problem solving and decision making. These ways affect their understanding of the text. This cause everyone has different comprehending in reading a text.

Reading Comprehension is related to the Field Dependence-Independence dimension of cognitive style. In this case, the researcher sees that the Field Independence 
students are more detail-oriented and can separate readily an item from its context. It makes them good at reading comprehension. In other side, the Field Dependence students are grouporiented and insufficient separate an item from its context and they are also dependent on authority. It makes them difficult to analyze the text.

Based on explanation above, the researcher wants to find out whether any significant correlation between cognitive style and students reading comprehension by making research about the correlation between cognitive styles and student's reading comprehension at the eleventh grade students in SMAN 3 Batam in the academic year 2015/2016.

\section{METHODOLOGY}

In this research, the researcher used "quantitative method". According to Sugiyono (2012:14), quantitative method is research method are based on the philosophy of positivism, used to examine the population or a particular sample, data collection using research method instruments, analysis of quantitative data, in order to test the hypothesis that has been established. There are many principles that go along with quantitative research, which help promote its supposed neutrality. Quantitative research generally comes later in research project, once of the scope of the project is well understood.

The main idea behind quantitative research was to be able to separate things easily so that they can be counted and modeled statistically to remove factors that they may distract from the intent of the research. Quantitative research involved gathering data that is absolute, such as numerical data, so that it can be examined in as unbiased a manner as possible. The result of quantitative was collecting numbers, which can be subjected to statistical analysis to come the result.

In this research, the researcher used corelational research to find out the significant correlation between cognitive style and student's reading comprehension. The population in this research was in second year of SMAN 3 Batam in academic year 2015/2016. Totally in all classes was 271 students divided into 8 classes. In this research, the researcher used cluster random sampling as a sampling research. According to Darmadi (2011:49), cluster 
random sampling is a method to take part of population randomly in a group. So, each group or class got same opportunity to be selected to become part of sample.

\section{Technique of collecting data}

\section{Embedded Figures Test}

EFT (Embedded Figures Test) was a perceptual test in the form of multiple choice test consisting 50 items. The subject must locate a previously seen simple figure within a larger or more complex figure that has been designed to obscure or embed the simple figure. The indicator of EFT was based on Witkin's Theory.

Table 1. Indicator of EFT based on Witkin's theory:

\begin{tabular}{llcc}
\hline No & Indicator & Item & Total \\
\hline 1 & $\begin{array}{l}\text { Locate a simple figure or a vertical position in a } \\
\text { complex context. }\end{array}$ & 50 items \\
\hline
\end{tabular}

Assessing: (Maghsudi in Onyekuru, 2015:82)

Field Independence $\quad$ : Score $\geq$ Mean plus standard deviation

Field Dependence $\quad$ : Score $\leq$ Mean minus standard deviation

The rest are ambivert

\section{Reading Comprehension Test}

The test of reading comprehension was in the form of multiple choice test consisting 30 items. The researcher gave 4 alternative answer in each item (A,B,C,D). The researcher took the question from previous question of National Exam in 2012. The indicators of Reading Comprehension Test were taken from Brown Theory. The researcher picked 5 indicators of Brown Theory considerate the characteristics of Field Dependence and Field Independence.

To measure the validity and reliability of the both of test above, the researcher used: 


\section{a. Validity Test}

Sugiyono (2012:121) mentions that the valid instrument can be used to measure what should be measured. Using a valid instrument in data collection, it was expected that the research results will be valid.

In this research to know validity of the test, the researcher used item validity Correlational Point Biseral. The reasearcher used this formula because Correlational Point Biseral is used to count validity item of test in multiple choice form. The formula was: (Sudijono, 2012:258)

$$
\mathbf{R}_{\mathrm{pbis}}=\frac{m p-m t}{s d t} \sqrt{\frac{p}{q}}
$$

Explanation:

$$
\begin{aligned}
& \mathrm{r}_{\mathrm{pbis}} \quad \text { = coefficient correlation biseral } \\
& \mathrm{m}_{\mathrm{p}}=\text { mean score of items who answered correctly } \\
& \mathrm{m}_{\mathrm{t}}=\text { mean of total score } \\
& \mathrm{sdt}=\text { standard deviation } \\
& \mathrm{p}=\text { proportion score of items who answered correctly } \\
& \mathrm{q}=\text { proportion score of items who answered incorrectly }
\end{aligned}
$$

The data is valid if $r_{\text {counted }}>r_{\text {table }}$ but, if $r_{\text {counted }}<r_{\text {table, }}$ then the data is not valid.

\section{b. Reliability Test}

Reliability is consistency of measuring instrument, to test on respondent consistency to answering the question on the test. To measure the reliability of the test, the researcher used KR 21 below: (Sugiyono, 2012:186)

$$
\mathbf{r}=\frac{k}{(k-1)}\left\{1-\frac{M(k-M)}{k \cdot s t^{2}}\right\}
$$

$$
\begin{aligned}
& \text { Explanation: } \\
& \mathrm{r}=\text { coefficient of instrument reliability } \\
& \mathrm{k}=\text { total of instruments' item } \\
& \mathrm{M}=\text { mean of total score } \\
& \mathrm{St}^{2}=\text { total variant }
\end{aligned}
$$


Table 2. Interpretation of reliability

\begin{tabular}{cc}
\hline Coefficient interval & Reliability \\
\hline $0.80-1.000$ & Very high \\
$0.60-0.799$ & High \\
$0.40-0.599$ & Moderate \\
$0.20-0.399$ & Low \\
$0.00-0.199$ & Very low (not reliable)
\end{tabular}

\section{Technique of analyzing data}

In this study the researcher adopted the procedure by Maghsudi (in Onyekuru, 2015:82) that used Mean \pm Standard deviation as boundary points:

$$
\begin{aligned}
& \mathrm{FD} \leq \text { Mean }-\mathrm{SD} \\
& \mathrm{FI} \geq \text { Mean }+\mathrm{SD}
\end{aligned}
$$

The rest are ambivert

\section{RESULTS}

Data of this research was taken from 65 students at eleventh grade in SMAN 3 Batam. The data was score of Embedded Figures Test (EFT) and Reading Comprehension Test. The researcher grouped the students into Field Dependence and Field Independence based on the score of their EFT. Based on the boundary points by Maghsudi (in Onyekuru, 2015:82), the researcher had classified the students in to Field Dependence, Field Independence, and ambiverts (neither FD nor FI) from their score in EFT. The researcher got:

Table 4. Student's Classification in FD/I

\begin{tabular}{ll}
\hline Classification & $\mathrm{N}$ \\
\hline Field Dependence & 18 \\
\hline Field Independence & 21 \\
\hline Ambivert & 26 \\
\hline Total & 65 \\
\hline
\end{tabular}


In Field Dependence, 21 students are include in Field Independence and 26 students who were found to be ambiverts were exclude from this study. Thus, the data of this research is only 39 students of Field Dependence and Field Independence students.

Table 5. Comparison of FD/FI students in reading comprehension test

\begin{tabular}{lccccc}
\hline Students & N & Mean & Median & Mode & SD \\
\hline Field dependence & 18 & 69.50 & 73.5 & 77 & 10.22 \\
\hline Field independence & 21 & 88.81 & 87 & 87 & 2.69 \\
\hline
\end{tabular}

The result of EFT and Reading Comprehension Test showed that students in Field Dependent had lower score in reading comprehension than students in Field Independent. It was caused by their characteristics in perceiving and processing the information from the text. By testing hypothesis used Spearman Ranked Correlation and counted Z value, the researcher get the value of $\mathrm{Z}_{\text {counted }}$ is greater than $\mathrm{Z}_{\text {table. }}$. It explains that variable $\mathrm{X}$ (cognitive style) has significant correlation with the variable Y (reading comprehension). It means that student's reading comprehension is influenced by their cognitive style. The field dependences are more fixed to the explanation format that has been proposed and have a tendency to accept information without restructuring and reorganizing it. Field independences are more likely to create their own models when trying to understand a perceived field. In Reading comprehension the students should construct the meaning in order to find the main idea, implied detail, grammatical features, detail information and vocabulary in context. Either Field Dependence students or Field Independence students can easily to find detail information and grammatical feature in the text. For detail information they can find the answer because it was exactly written in the text. In grammatical feature, most of the students are able to representing the reference of pronoun. These indicators need carefulness. Field Dependences have characteristics tendency to accept information without restructuring and reorganizing it and affected by prevailing context. It made them difficult to find main idea and implied detail because they difficult to construct their own perception and to find the information that not exactly written in the text. While field independences are effective at analysis and restructuring elements, they could build their own perception of the text. It made them find main idea and implied detail easily. Most of Field Dependence students are difficult to find the vocabulary in the context. To find the vocabulary in the context student 
should have rich vocabulary and be able to match with the context. Field Independence students are self-structuring, it makes them good in finding synonym or antonym of vocabulary and matched it to the context. These are the different ways of Field Dependence and Field Independence students in processing information. That makes them have different achievement in reading comprehension. Thus, there is a significant correlation between Cognitive Style and Student’s Reading comprehension.

\section{DISCUSSION}

Based on description on the previous chapter, the researcher concluded:

1. The statistical analysis of cognitive style and reading comprehension showed that value of coefficient correlation $(r)=0.836$. It means cognitive style and reading comprehension have very high correlation. The level of significance $\mathrm{Z}_{\text {counted }}$ is 5.157 that higher than $\mathrm{Z}_{\text {table }}$ 1.96. It means cognitive style and reading comprehension have significant correlation.

2. Ho is rejected and Ha is accepted. There is a Significant Correlation between Cognitive Style and Student's Reading Comprehension.

Considering the research finding, where there was a strong correlation between Cognitive Style and Student's Reading Comprehension, the teachers are expected to match the style of teaching to suit student's Cognitive Styles in order to get the effective learning. Where field dependent students are better at learning material with human context and field independent students are better at learning impersonal abstract material. In giving feedback, field dependent students require affirmation from the teacher while field independent students may find self determined feedback sufficient.

\section{REFERENCES}

Darmadi, Hamid. (2011). Metode penelitian pendidikan. Bandung: Alfabeta.

Onyekuru, Bruno Uchenna. (2015). Field dependence-Field independence cognitive style, gender,career choice and academic achievement of secondary school students in Emohua local government area of rivers state. Journal of Education and Practice, 6, 76-85. Retrieved from: http://files.eric,ed,gov/fulltext/EJ1081668.pdf. 
Sugiyono. (2012). Metode penelitian pendidikan: Pendekatan kuantitatif, kualitatif, dan R\&D. Bandung: Alfabeta. 